\title{
West German agency launches early bid for more funds
}

Bonn

THE Deutsche Forschungsgemeinschaft (DFG) has scored an early success in its campaign for an increased budget. West German Education Minister Jürgen Möllemann (Free Democrat) announced last Friday that he will campaign for a 5 per cent annual increase for DFG, the chief source of research grants in West Germany, in each of the next 5 years.

The proposed increase is by no means a certainty, since all eleven Länder (states) must first approve it. On the federal level, Möllemann must secure the support of the

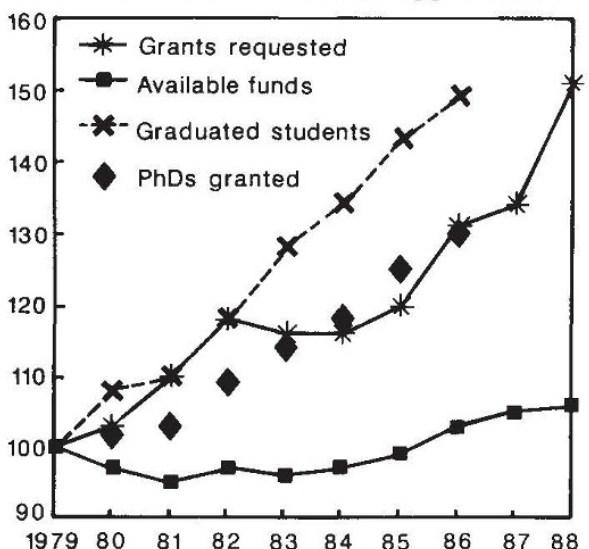

Grants requested and funds available from the $D F G$ to 1988. The 1979 figures are taken as 100; no allowance is made for inflation.

rest of Chancellor Helmut Kohl's cabinet. Three-fifths of DFG's support comes from the federal government and the rest from the Länder. Asked about the chances of success, Möllemann said that an annual increase of 5 per cent is "realistic and achievable". The agency's budget this year is DM1,188, but the 1990 budget will not be finally approved until December.

DFG President Hubert Markl had sounded an alarm earlier last Friday when he declared that basic research support had "dramatically worsened" in 1988 . $\mathrm{He}$ predicted grave consequences if DFG did not receive a 6.5 per cent increase in 1990 .

The nub of Markl's case is that, in 1988, DFG had to reject the highest percentage of grant applications in its history: only 48.4 per cent of individual applications were funded. And for the first time, fewer than half of the Schwerpunktprogrammen (priority programmes) applied for could be supported (see Nature 336, 510; 1988).

Part of the difficulty is that research is booming at West German universities, so that there are more applications for grants than ever. Markl expects even more competition for DFG funds in the future: 40 applications have already arrived for Sonderforschungsbereichen (special collaborative programmes), half of them planned to begin before 1990 .
There are also more students than ever crowding West German universities, which Markl says will be looking to DFG to support graduate and postdoctoral studies for the next decade. Markl says that if these people are forced out for lack of funds, their potential will be lost.

One consequence of the high rejection rate is the disaffection of DFG's (unpaid) referees, who Markl says are "fed up" with reviewing good proposals which are not supported. But he resists the suggestion that greater competition might enhance the quality of West German research: that point was reached years ago, he says, so that the applications now being turned down are of the highest quality. Markl is concerned that West Germany will be "left behind" if it does not increase research support. He points to the planned 10 per cent increase of the budget of the US National Science Foundation and the similar increase for the corresponding body in Japan.

DFG received only a meagre increase in 1988, despite Markl's impassioned appeal in June, which is why he has felt impelled to act earlier this year, writing to Kohl and the heads of the Länder in January. He was visibly pleased by Möllemann's announcement last Friday.

The proposed increase is likely to be discussed at the next conference of the heads of the Länder on 10 March. Well-off Länder such as Baden-Württemberg and Bavaria are expected to take up DFG's case, while Möllemann's announcement will put political pressure on the others.

Steven Dickman

\section{Soviet psychiatrists at odds on eve of visit by United States}

\section{London}

THE campaign by Soviet psychiatrists to rejoin the World Psychiatric Association may be impeded by an open letter to the Soviet Academy of Medical Sciences by Dr Viktor Gingilis, head of the genetics laboratory of the Brain Research Institute at the All-Union Research Centre for Mental Health. The letter is a direct attack on the director of the institute at which Gingilis works, Dr Marat E. Vartanyan.

As director of the Centre for Mental Health (since December 1987), Vartanyan is in a position to influence the practice of psychiatry in the Soviet Union. The letter, first circulated at the end of last November, comes on the eve of the beginning next week of a 2 -week tour of Soviet psychiatric hospitals by a group of 20 US psychiatrists and other experts.

The charges levelled against Vartanyan, who is known in the West for his categorical denials that sane but politically suspect persons were ever incarcerated in Soviet psychiatric hospitals, include many of a personal nature. But Gingilis's general complaint is that Vartanyan is seeking to shift onto others his own burden of responsibility for a practice in which he was "most active".

Reached by telephone at the institute, Gingilis acknowledged authorship of the letter, but said that he himself had not sent it abroad or to the media. Asked whether, in that case, he would prefer Nature not to report it, he replied "That's your affair".

Vartanyan was not available for comment, being about to leave on a business trip. His assistant, Dr Georgii Morozov, said, however, that Vartanyan knew all about the letter, and thought it a matter of little importance. "If Dr Vartan- yan could speak to you, he would explain itall", Morozov said. An arrangement that Vartanyan would call Nature back at an agreed time failed to materialize.

Gingilis says that Vartanyan's election to his present post (necessary under the new democratization) was rigged, and went against the wishes of the majority of the centre's staff. His letter goes on to suggest that Vartanyan and his wife, D. D. Orlovskaya (who is at the same institute) have risen in academic distinction on the strength of the work of others, many of whom have subsequently been hounded into resignation or emigration. The letter says "I am the real author of almost all the publications and research initiatives attributed to M.E. Vartanyan in the field of medical genetics".

Gingilis claims that his own work, together with that of I. V. ShakhmatovaPavlova, was misappropriated by Vartanyan to support his appointment as corresponding member of the Soviet Academy of Medical Sciences. He says that Vartanyan's personal power base has remained secure because few have been prepared to speak up in public, but "after twenty years of serf-like dependency on Vartanyan", he has decided to speak out "with all responsibility and with a clear understanding of the possible consequences".

It remains to be seen what will be the effect of this letter on next week's visit by the US group. The Soviet authorities maintain that all dissidents have either now been released, or are being processed for release, from psychiatric hospitals. The visitors will be able to examine patients whom they choose and to visit at short notice psychiatric hospitals which they select.

Vera Rich 